\title{
Frame Narrative Technique: Paralleled Heterotopias in Mohamed Rageh's $A$ Quarter Citizen
}

Nermine Ahmed Ibrahim Gomaa

Associate Professor, Horus University, Egypt.

\begin{abstract}
The research has a threefold literary approach with a psychological, philosophical as well as a technical perspective. It aims at examining the narrative technique used by Egyptian novelist and script writer Mohamed Rageh in A Quarter Citizen. The research seeks to show Rageh's novel as belonging to the narrative therapy type. It suggests that following this type of therapeutic narrative, Rageh builds heavily on the Michael Foucault's concept of 'heterotopia' and frame narrative technique. This could be traced in the novel's presentation of different types of heterotopias together with a form of frame narrative exemplified in his presentation of a script- within- a novel technique. This sets narration in Rageh's $A$ Quarter Citizen as starkly built on parallelism and juxtaposition. In his scenanovel, as he ventures to calls it, Rageh juxtaposes the protagonist's true experience with a different version of it rendered in the form of a script. A further type of parallel in the novel is that between
\end{abstract}

different forms of 'heterotopias' especially the prison as heterotopias of deviation where the larger part of the novel's actions take place. In light of this, the research seeks to trace the extent to which narration was an aid to the novel's protagonist and how far it helped him to relieve his psychic disturbances resulted from his incarceration experience. In so doing, the research poses the question whether narration in Rageh's A Quarter Citizen proves to be therapeutic or not and if it successfully follows the two prerequisite steps of narrative therapy namely externalization and suggestion. Further questions are concerned with the therapeutic role played by the script/ heterotopia and the models of identity building suggested by the script.

Keywords: Narrative therapy, scenanovel, heterotopia, Incarceration experience, prison, Frame narrative technique, trauma, parallelism, heterotopia of deviation, heterotopia of illusion, heterotopia of compensation, crisis heterotopia, betrayal, therapeutic effect. 


\section{Frame Narrative Technique: Paralleled Heterotopias in Mohamed Rageh's $A$ Quarter Citizen}

Nermine Ahmed Ibrahim Gomaa

Contemporary philosophy has always been preoccupied with existential issues such as the suggestion of alternative methods of identity building and the redefinition of space from a different ontological perspective. French philosopher Michael Foucault proposes that, unlike the nineteenth century's too much obsession with history and historical themes, the mania of the present age is a redefinition of space. In this respect, Foucault puts it that "We are in the epoch of simultaneity ... we are in the epoch of juxtaposition, the epoch of the near and far, of the side-by-side, of the dispersed." ("Other spaces"22). In line with the age's preoccupation, Foucault seeks to reconceptualize space; he, consequently, develops his concept of 'heterotopia', a term that has been coined to refer to a selffinding remote far-off space that has, as the paper suggests, a therapeutic as well as an enlightening effect. Beside Foucault's term of 'heterotopia' that represents the research's philosophical framework, frame narrative technique stands out as its technical approach. Both terms are subservient to narrative therapy,

Narrative therapy has been widely known as a term first initiated by Michael White, David Epston, among other pioneer psychologists. The term highlights the therapeutic role played by narration in releasing psychic and mental disorders. The Dulwich Centre, Adelaide, founded by Michael White proposes that:
A narrative therapy assists persons to resolve problems by: enabling them to separate their lives and relationships from those knowledges and stories that they judge to be impoverishing; assisting them to challenge the ways of life that they find subjugating; and, encouraging persons to re-author their own lives according to alternative and preferred stories of identity, and according to preferred ways of life. (Besley73-74)

Narrative therapy counts heavily on two significant processes: externalizing and suggesting. The externalizing process advocates a fictional distancing away of people's distress, traumatic incidents and misfortune in a narrative form that tends to be both therapeutic and beneficial (Lotfi 13). In Narrative Means to Therapeutic Ends, Michael White and David Epston meditate upon this therapeutic distancing technique as they write:

Externalizing is an approach to therapy that encourages persons to objectify and, at times, to personify the problem that they experience as oppressive. In this process, the problem becomes a separate entity and is external to the person or relationship that was ascribed as the problem. Those problems that are considered to be inherent, as well as those relatively fixed qualities that are attributed to persons and to 
relationships, are rendered less fixed and less restricting. (38)

By giving a fictional narrative version of life events, troubles and actions, narrative therapy offers means of judging our lives from different perspectives and therefore a possibility of soothing psychic tensions and damages. Besides, a second therapeutic functional step of narrative therapy is that of suggesting recommended alternative images of identity. In this way, it draws heavily upon the belief that identity is mainly built by fictionalized images of actual life presented in narration (Lotfi 1912-13).

According to Tina Besley, narrative therapy, as essentially coined by Michael White and David Epston, is greatly indebted to many poststructuralist theorists including Michel Foucault (72-74). Besley could find enough influence of Foucault's concept of power on narrative therapy's ideology. To Foucault, power has a benevolent, constructive as well as malevolent, tyrannical effect that plays its role in identifying and locating us, (81). Closely related to power, in Foucault's philosophical thought is society's dividing practice that divides and separates those who prove to be dissimilar and who deviate from the group's framework code of conduct (Madigan 266). Being concerned with society's dividing practice, Foucault is motivated to study isolated out-of-self spaces where individuals are excluded, spaces that he terms 'heterotopias', a further concept of Foucault's that, according to the research, figures prominently in narrative therapy's ideology.

Speculating upon the origin of the concept of heterotopia, Peter Johnson proposes that heterotopia has a Greek origin; it is made up of the two words heteros and topos that mean respectively another place; it is used as a space dissimilar to utopia (77). Originally, heterotopia is a term that has a medical background; it is a term that signifies a state of dislocation or misplacement where a tissue is notoriously placed elsewhere yet has no dangerous implications (Johnson77). Foucault defines a heterotopia as a place that embodies challenges and upset, at one and the same time, cultures 'real places. He describes it as:

kind of effectively enacted utopia in which the real sites, all the other real sites that can be found within the culture, are simultaneously represented, contested, and inverted. Places of this kind are outside of all places, even though it may be possible to indicate their location in reality. Because these places are absolutely different from all the sites that they reflect and speak about, I shall call them, by way of contrast to utopias, heterotopias. (“Other Spaces” 24)

Heterotopias are places people dwell in at certain periods and for specific reasons; Foucault identifies "the prison, the cemetery, the theatre, the library, the museum, the brothel, the ship and the mirror" as types of such mythical places. They are some self- isolated enclosed spaces that redefine existing, taken-forgranted notions of space (Knight 8). In Johnson's words, "They mirror, reflect, represent, designate, speak about all other sites but at the same time suspend, neutralize, invert, contest and contradict those sites"(78).

Foucault suggests that every culture has its varied changeable heterotopias that 
can change with the passage of time. However, the same heterotopia's function differs from one society to another and from time to time (Foucault et a 1"Other Spaces" 25). Heterotopias, like the cinema and the stage, might present, in parallel at one and the same time, a variety of different nonrelated spaces. This makes them challenging spaces that defy the borders of time where all time boundaries are destroyed and where time is "accumulating" (Knight 1(. More important still, heterotopias are closed places where people either have to enter by force, like prison, or are only allowed there with certain rituals and purification acts. Other heterotopias are not accessible though they sound to be at hand and reachable, however existing in such places is no more than delusion as they actually dismiss us (Foucault et al "Other Places" 26). Though, forms of heterotopia are so diverse, yet no form is found isolated or standing on its own; all are so intricately related that they can only function in relation to one another resulting in more casual troubling spaces (Johnson 84).

Foucault divides heterotopias into two groups, "crisis heterotopias" or rather spaces specified for people in physical ailments and "heterotopias of deviation" like places for criminals and mentally disturbed individuals. Two further categories of heterotopia are "heterotopia of illusion" that is an unreal space that highlights real space as more unreal and "heterotopias of compensation" that is an orderly space that exposes disorder in the immediate milieu (Knight 18). In light of such categories, heterotopias have a double function that could only be seen in relation to all existing spaces. Their functions lie between the two extremes of creating an area of complete delusion that depicts factual spaces as more illusory or to build an area that is a further actual space that, unlike our real space, is unspoiled and righteous (Foucault et al "Other Spaces" 27). A further function of a heterotopia as casually suggested by Foucault in "Of Other Spaces" is that of transformation as it is a place where a type of transformation or rather metamorphosis occurs (Bachinger 166). Just as externalizing the problem effects its transformation, externalizing the individual's self, in a heterotopia is bound to cause a sort of transform.

Of all categories of heterotopia, Foucault is much more concerned with confinement heterotopias especially one type of heterotopias of deviation, namely prison. He gives much concern to prison in his Discipline and Punish where he discusses the development of disciplinary systems since early times until it reaches its present forms. Being concerned with confinement heterotopias, Foucault is preoccupied with forms of Otherness including the mad and the prisoner. As suggested by Hubert L Dreyfus and Paul Rabinow, Foucault's critical thought is concerned with the constitution of human beings as subjects, the treatment of human beings as objects, the relationship of punishment and surveillance (9). In his Discipline and Punish, discussing the history of disciplinary technology or rather punishment techniques inflicted upon criminals throughout classical periods, Foucault highlights the transformation process that occurs in the heterotopia of prison; he concludes that prison disciplines not only develops a prisoner's skills but increases his subjugation as well. $\mathrm{He}$ writes:

The historical moment of the disciplines was the moment when 
an art of the human body was born, which was directed not only at the growth of its skills, nor at the intensification of its subjection, but at the formation of a relation that in the mechanism itself makes it more obedient as it becomes more useful, and conversely ... . The human body was entering a machinery of power that explores it, breaks it down and rearranges it . . . . Discipline produces . . . docile bodies . . . . [It produces] an increased aptitude and an increased domination"(qtd.in Dreyfus et al 154)

Apart from heterotopia, Foucault meditates upon the concept of utopia as an unreal cite that shows an ideal image of society. Defining Utopias Foucault writes, "They are sites that have a general relation of direct or inverted analogy with the real space of Society. They present society itself in a perfected form, or else society turned upside down, but in any case these utopias are fundamentally unreal spaces"(“Other Spaces”24). Contemplating upon the function of utopia in Foucault's thinking, Peter Johnson suggests that utopias are fantastic compensating areas "in the form of daydreams and fantasies, critiques of existing conditions and the capacity to provoke the desire for transformation" (82). The two types of space are said by Foucault to meet at a further point, the mirror that is both a utopia and a heterotopia, though it is in Foucault's words "a placeless place" (Foucault et al "Other Spaces"24). Iwan Sudradjat argues that to Foucault, a mirror's unreal reflected image classifies it as a utopia however, the mirror itself is a factual thing that shows the relationship between one and his/her own image, the fact that labels it as a heterotopia (29).

Applying the paper's threefold approach that depends on narrative therapy, frame narrative and the concept of heterotopia, the novel figures prominently as following the therapeutic narrative line of narrative therapy that builds heavily on the two steps of externalizing and suggesting. Most of the actions of Rageh's prison narrative novel, A Quarter Citizen take place in the heterotopia of prison, one that has a variety of further heterotopias. For the fulfillment of the two therapeutic steps of narrative therapy, Rageh draws upon Foucault's concept of heterotopia doubled with the frame narrative technique. In so doing, he presents a frame narrative heterotopia, which he terms a scenanovel, exemplified in a script within the novel. The novel also depends on parallelism that further distance and distract the individual's agonizing stories. Rageh skillfully parallels the two narrative schemes: the narrative line of the novel and the script. This gives the reader two paralleled alternatives of narration, namely script and novel and also provides two major paralleled heterotopias. This double narrative technique of Rageh's is one that is significantly relevant to prison narrative; it shows one narrative type (script) imprisoned in the other (a novel) and invites the reader to reflect upon a differently rendered world.

In A Quarter Citizen, Rageh reflects, criticizes and subverts real life through his presentation of the heterotopia of prison as a correctional facility institution. Prison is meant by Rageh to be a heterotopia of compensation that is an ordered heterotopia underlying real life's disorder. Abed, the novel's protagonist is sent to prison due to an uncovered check granted 
to his dishonest fiancé Wafaa. Before going into the incarceration experience, Abed has had an idea about prison that is inhuman and merciless. Yet he intends to depict real-life prison, in his prison heterotopia, as more brutal and disordered than the stereotypical image of prison presented in the heterotopia of movies. Abed says, "I discharge my mind of any image of prison presented in $\mathrm{TV}$ or in movies. We are here in real life" (38). The image of prison as a form of a heterotopia of deviation reflects, criticizes and subverts the real image of life. Rageh describes the image of Borg Elarab prison, where he is sent, as he writes, "An oppressive land that is trodden by no prophet where dogs are trained to fuck prisoners!! Beside the merciless police inspectors and their more cruel bludgeons" (28).

The narrative of prison criticizes existing forms of power. Prison, the heterotopia of compensation, is seen as an isolated primitive heterotopia that has its own language and laws where barter is the rule of transactions among prisoners and where the common currency is cigarettes. Rageh has so far set prison as a completely independent heterotopia as he describes it as having "its own vocab and dictionary"(156). Criticizing real life as reflected in the heterotopia of prison, Rageh reveals an overthrown of Foucault's power of knowledge and sets instead barbarism as life's code; it is a space that scorns literacy. In this respect Abed says:

Throughout my life I have been fighting to become a literate, intelligent individual and a writer.. But here in prison the pyramid is turned upside down.. all these vocabs disgrace its owner. I could never find myself and it is not given the due respect outside these bloody walls and in between I was crashed. (81)

Instead of correcting his criminal misbehavior to qualify him to be a perfect individual, prison causes Abed to lose faith, another evidence of the imperfection of life and its dividing practice. Ironically enough, Abed, whose name suggests piety and devoutness, moves to a space of disbelief and blasphemy. This is made clear in recurrent utterances of him like: "Yesterday I was so fed up that I whispered to God before sleeping blaming him for creating me then forgetting and oppressing me ... I no longer do my prayer and know not if I would go back or not"(39). A further suggestion of Abed's loss of faith is illustrated in the way the protagonist accuses God Himself of injustice as he says:

I have been beseeching God for a long time yet he never accepts. I cannot comprehend what I have done to deserve such severe punishment and suffering. Deep inside I feel angry with everything even God. I feel angry with Him as he allows my oppression and let me put into prison ... I know perfectly well that this is blasphemy. (Rageh 40-41)

Rageh's narrative therapy scheme is also equipped with parallelism that helps to further distance and distract the individual's suffering. In line with Foucault's description of heterotopia as encompassing different heterotopic spaces, Rageh's description of the heterotopia of prison shows it as including a group of different sub-heterotopias. It has football playgrounds, a library, a school, an activity hall, a hospital, the dorm of the 
officers, death rows and the temporary heterotopia of the celebration held when a prisoner finishes his due period in prison and has, therefore, to leave. This suggests all related ideas evoked by Foucault. Further heterotopias are torment and torture rooms where prisoners go completely naked except for their under shorts. There, they are received with some horrible inspectors who inflict upon them the severest techniques of torture starting from being hit with horrible thick sticks to allowing their trained dogs to merciless disintegrate them both physically and sexually, a scene that is watched by an audience of other prisoners. In such rooms a prisoner is left alone with just a tiny slice of bread, some little cheese and some little water (Rageh 152). To these heterotopias, Rageh adds, in parallel, a new one: a script that encompasses in itself a variety of other heterotopias. The script represents a frame narrative heterotopia, it is a heterotopia of illusion that " exposes every real space, all the sites inside of which human life is partitioned, as still more illusory" (Foucault et al "Other Spaces" 8). It offers an alternative prosperous plan for the protagonist.

Like prison, the script is in itself a typical heterotopia that escapes nothing of Foucault's term. It encompasses a number of other heterotopias like the prison, the library, the playground, etc. It is a powerful heterotopia as it breaks up with the element of time; it moves freely forward and backward disrupting the linear order of actions. Thus, Rageh skillfully suggests, creates and introduces wide-ranging paralleled heterotopias through his use of frame narrative technique, represented in the script that goes in parallel with the actions of the novel. The script itself suggests Foucault's heterotopia of cinema with all its implications and unreality and its introduction of non-related heterotopias. Like reality presented in the novel, the script has heterotopias of prison, library, and playground among other heterotopic areas.

Rageh seeks to fulfill three therapeutic targets in his frame narrative heterotopia, the script: the distancing of agony and psychic disturbances, the suggestion of different models of identity and the presentation of a transformation process. Through his own heterotopia of illusion, the script, Abed seeks a state of transformation where he can be transformed into a powerful opportunist. Abed, as a result, decides to give up his citizenship and determinately proposes a three-item wish-to-do list. He says, "No more good spirits.. even no more a human. I have turned into a machine whose three major goals are: the abjection of female, taking revenge and getting a different nationality" (Rageh 77). These three items on Abed's wish-to-do-list are going to be a criterion according to which the development in his identity and, consequently, the success or rather failure of the cause of narrative therapy are to be judged.

Rageh's script is a heterotopic area where the two prerequisite steps of narrative therapy, the process of distancing the agony and that of suggesting better models of identity building, are to be fulfilled. This is done through Rageh's two techniques of revision and subversion on the one hand as well as religious allusion on the other. The script is a replica of Abed's story but with certain changes that are meant, as dictated by narrative therapy, to dissociate the link with the protagonist's actual experience and to render "preferred 
stories of identity" (Besley 74). The revision is to be traced in the title, the names of the characters and in the actions as well as in their order. The script is built on the story's two core incidents, the love relationship that sends Abed to prison and the incarceration experience. Rageh's script revises the actual incidents and devises an alternative context that is meant to be therapeutic and didactic.

Though the script, as a frame narrative, seeks to distance away both the agony of betrayal and of the incarceration experience, yet, as a first step, it deliberately discredits the more disastrous experience, prison. Thus, for so doing, the script/heterotopia, in a therapeutic manner, disrupts the linear order of actions presented in the novel and revises the actions' importance as well. It starts with a flash back technique; before the actions starts, it shows Yusuf, Abed's duplicate, in jail at which point the starts relating Yusuf's life a year before prison. He is a self-interest bank clerk who has completely changed after his engagement. The pious, devoted Yusuf stops praying to God and is completely dedicated to Wafaa, his fiancé, disobediently neglecting his mother both emotionally and financially. The script's disruption of the novel's order of actions that start in prison is meant to highlight woman betrayal, rather than the prison experience, as the protagonist's trauma. It sacrifices and weakens the experience of imprisonment that is more devastating for him, for the sake of the way the protagonist's love story sends him to jail showing betrayal as more devastating and shocking.

Such a weakening of agony through a subversion of the importance of actions is reminiscent of Freud's trauma resolving technique where the agony is destabilized once the past traumatic action is represented in the present with a difference (Nicholas 55). The revision of time and actions makes the individual feel that it is no more part of his/her experience. The script, therefore, repeats the main trauma showing it as less significant and shifts the protagonist to a new area of interest to distract the main trauma by shifting the interest to a less agonizing incident, Wafaa's betrayal. Beside the subversion of the linear order of actions, the shift of interest is also done by devising a second betrayal plot symbolized in the relationship the script presents between Yusuf and Nour who, like Wafaa, betrays him. Thus, once the incarceration experience is successfully destabilized and weakened, Rageh, as a second step, inserts the second betrayal plot that is meant to restore the trauma caused by Wafaa's betrayal to be weakened and avenged for. He therefore, therapeutically handles the two traumas respectively.

A further revision in the script could be seen in the protagonist's name and in the title of the script itself; both are significantly revised. The script is written by Abed; in place of A Quarter Citizen, it is called Nothing New or rather Behind Prison Siege. The revision of the novel's title is greatly therapeutic as well as suggestive. The title Nothing New is meant to lessen the shocking element of the story and to mitigate the protagonist's agony by showing that this so happens. This destroys the implied feelings of disintegration and oppression suggested by the original title. Keeping the fiancée's name, Waffaa, unrevised is highly significant. The choice of the name is ironic as it cynically means faithfulness. Keeping the same name is meant to destroy the second trauma of female 
betrayal showing female unfaithfulness as something common and recurrent.

The revision of the protagonist's name, on a deeper level, is regarded as implying a significant religious allusion. Abed's name is significantly revised to be replaced in the script with Yusuf. The name has its religious significance. It implicitly alludes to the story of prophet Yusuf, the son of prophet Yakub who, like Abed, has himself been unjustly put into jail because of an unfaithful woman. As prophet Yusuf refuses to comply with her seduction, he was sent to jail. The reference to prophet Yusuf's issue is greatly supportive and therapeutic; it shows that history repeats itself and it suggests that even prophets are destined to suffer the fact that might destabilize Abed's traumatic feelings and help him to recover. The choice of the name of Yusuf seeks to show a disparity between a heterotopia and reality highlighting real life as more oppressive and devastating as it sends honest people to prison. The fictional Yusuf is a human who has his own imperfection and faults; he is not as virtuous as prophet Yusuf where the former gives himself completely to his sexual affair with his fiancé and is partially held responsible for his sentence as he grants her the uncovered check. Unlike him, prophet Yusuf is put into jail as he refuses to have a sexual affair with Zulaikah, the wife of Aziz. Thus, the script/heterotopia keeps up with Foucault's definition of heterotopia as a space that criticizes life's imperfections.

Furthermore, the allusion to prophet Yusuf in the script / heterotopia suggests Foucault's second term, Utopia. It is an unreal spiritual Utopia of prophets' ethics set in sharp contrast with the novel's heterotopia of real life prison where humans lose faith and submit themselves to vices and immorality. Unlike Prophet Yusuf, who never loses faith in God, the fictional Yusuf stops praying to God. Besides, prophet Yusuf has later on forgiven the oppressive woman yet, in the heterotopia of a frame narrative script, the fictional Yusuf turns into an opportunist who seeks revenge and who surrenders himself to a deviant plan that helps him to reassure himself financially.

The suggested allusion to Yusuf's religious incident has two major therapeutic functions. It suggests the possibility of identifying with a different alternate identity model of piety and devotion that is able to forgive and, as a result, is fated with a prosperous future. It alludes to a further juxtaposing heterotopia, the prison of a faraway time that belongs to the age of prophet Yusuf. Thus, Rageh helps his heterotopia to function more powerfully since Foucault suggests that, "The heterotopia begins to function at full capacity when men arrive at a sort of absolute break with their traditional time"(Foucaul et al "Other Spaces" 26). This again shows the heterotopia of the script as one of illusion that encompasses further heterotopias belonging to different times where one heterotopia helps to distance distress to another until it is all distanced and weakened. Thus, the script/ heterotopia, in a therapeutic manner, suggests two identity building alternatives: a prophetlike figure and an opportunist. The script, therefore, is not concerned with the protagonist's actual identity but rather with suggested alternative forms of identity. In so doing, it draws heavily on forms of narrative therapy that do not "speak of the 'truth' of people's identity but are 'accounts' that reflect who 'we are as 
multi-desired, as multi-motivated, and as multi-intentioned in life as our lives are multi-storied'" (White, "Therapists' lives" 231).

In the script/heterotopia, the process of distancing, that is a prerequisite to narrative therapy, is accompanied with a transformation process. Distancing Abed's agony, Rageh's script protagonist, Yusuf, expresses his inside suffering in prison saying:" All I have heard and seen in movies and TV never truly reflects what occurs in this bizarre strange world, a world where a prisoner's dignity is humiliated and his human nature's rights are ruptured. I am standing exactly on the edge of the divide between man and animal"(246-47). This distancing of Abed/Yusuf's sorrows is accompanied with a transformation hope. Consequently, the script/ heterotopia space witnesses a desired transformation in the fictional alternative figure of Abed, Yusuf. In place of the helpless Abed, Yusuf stole some important documents from the bank manager and blackmailed Kasem to give him the stolen documents. He has got a large sum of money in return for the papers. Yusuf starts his business career with the money through a partnership with Zaki. In no time, Yusuf has become a wealthy gentleman with a BMW luxurious car like the one Abed saw his fiancé Wafaa in with her rich suitor. A further transformation is testified when the opportunist Yusuf married the well-to-do Nour who has got an American passport. All such transformations in Abed's replica, Yusuf, are meant to reflect a prospective empowering conversion that is to solidify Abed. Here, Rageh's frame narrative technique proves to be therapeutic; it subverts all points of weakness in Abed and represents a new version of him who has got the power of money, prestige as well as of intelligence. This suggests a new born wealthy opportunist Abed. Hence, the frame narrative heterotopia becomes one of power and authority. It is a well-organized space that highlights real life's imperfection and disorder and presents a different model of identity, that of the powerful opportunist.

Rageh's script as a heterotopia of narrative therapy helps Abed to achieve his wish-to-do list either fictionally or actually. Yusuf's marriage to the American citizen Nour helps him to get a different citizenship, one of the major items on his list. When Yusuf meets Zakaria who refuses Yassin's proposal to marry his daughter because of Yusuf's experience as a prisoner, Yusuf says: "Now, thanks goodness, I have got millions, an American citizenship because my wife is American. To cut it short, I am regarded here in your country as a foreign investor" (Rageh 361). The other two items on his list, revenge and abjection of female are also achieved. Yusuf first rejects his wife's friend Sally by rejecting her emotional and sexual advances. Though Yussef's discovery of Nour's sexual affair with his partner Zaki finds no rushed abrupt reaction on his part, yet he has later on rejected her through divorce. Divorce, therefore, represents abjection and revenge at one and the same time achieved on the fictional level.

Beside the script, Abed's diary that he calls When Worms Ate Me Alive is a further frame narrative heterotopia. In this manner, Rageh not only distances his protagonist's agony but he scatters it as well, once in a script and then in a diary, until it is actually fragmented and distracted. He abruptly moves backward and forward in time, through his frame 
narrative technique (the diary and the script), to dissociate the link between the individual and his agony. The more Abed distances his life in the script, the more his character testifies a certain positive change. Having, for example, unfolded the suffering of the incarceration issue in the script, the high-spirited Abed says: "I will initiate my dreams from this place- a $6 \times 4 \mathrm{~m}$ room on whose floor thirty person sleep, where no stoves are allowed. The prevailing color is blue and the game's title is deterioration and humiliation. From here I achieve my miracle. Go ahead. I will proceed and nobody can set me back" (Rageh 192). Besides, Abed, as a result, restores his religious identity and his lost faith as he starts to do his prayers once again. However, the script is a more successful example of frame narrative than the diary. Unlike the script that has some changes that have therapeutic effect, the diary, that is a literal registration of Abed's suffering, seems to empower Abed's anguish. Relating the account of his love affair as literally as it occurs in his diary, Abed writes: "since yesterday I am obsessed with a state of dissatisfaction, weariness and worry especially after I wrote what I wrote. I thought that releasing what is inside on papers would relieve me. Yet this led to the contrary." (Rageh 222). This greatly recommends the script as more efficient for narrative therapy's distancing of negative experiences 'agonies as it carries enough changes unlike the diary, that literally duplicates the trauma.

The fact that the space covered by the script/ heterotopia is larger than the one covered by the novel's incidents implies that Rageh's frame narrative technique is meant to play the larger role in his narrative therapy novel. In so doing,
Rageh's frame narrative script/heterotopia, a distancing space of narrative therapy, proves to be a successful one. Each time Rageh comes back to the novel's main incidents leaving the script, he shows the script's therapeutic influence reflected in a transformation in Abed's character. This could be seen either in convincingly dismantling one of the items on his wishto-do list or in achieving another. Abed's defense of Egypt in a stiff argument with his prison mates is a perfect evidence of pulling into pieces his desire to give up his Egyptian citizenship and gaining a different one, a wish that is fictionally achieved in the script. Abed himself cannot understand the change of attitude he experiences. He says: "Today, there was a violent discussion between me, Arafa and Naser about Egypt as we see it. To my astonishment, I was the defending side who aggressively defended Egypt" (Rageh 375). This pulls into pieces his wish to get a different nationality. Hence, one important item in his wish-to-do list is overthrown, the fact that testifies a disappearance of one of the trauma's destructive consequences. A further mark of a change in Abed is reflected as he says: "Woman has completely vanished, with no return, from Abed Abd El Rahman's life.. did anybody see her?" (Rageh 377). However, this is regarded as a negative sign as he still has the aggression -againstfemales trauma created in him.

The last part of the script is greatly suggestive; it depicts the third item in his wish-to-do list, revenge, achieved fictionally. This is exemplified in telling Nour that her close friend Sally, who tries to show Yusuf as unfaithful, was actually chasing him. He allows her to listen to a recorded conversation between him and Sally when she tried to seduce him. 
Having revealed the fact that Nour has been deceived by Sally and that he discovered Nour's sexual affair with Zaki, Yusuf divorced Nour and left her completely broke down. The last scene is a flashback restoring decisive and painful moments in Yusuf's life. Scenes of past memories pass quickly including Wafaa in bed with him, Wafaa in Bassem's car, being forcefully beaten in prison, his first kiss to Nour and their weeding picture, the moment he saw Nour naked after betraying him with Zaki, his mother's kindness, Yassin at his new office and Omar hugging him when he is released from prison. Yusuf goes back to the present just to retreat once again to a past memory when he visited a physician just to discover his suffering from lung cancer.

Though the script shows some marks of positive transformation in Abed's replica that signify a successful distancing away of agony, yet still its highly therapeutic nature lies in suggesting a resolution for Abed's suffering. Having pondering over powerful prospective deviant attitudes taken by the protagonist as a defense mechanism and a means of self-assurance, the script has finally suggested that one has to achieve a state of intertextuality between heart and mind. It proposes that being too much minded with any of them is greatly destructive. The script also suggests that one should never forget the spiritual fact that God is there. In this respect, Yusuf's mother sums up her son's fatal flaw in three items: being, at first, too much minded with heart, then, being too much minded with mind and disregarding the spiritual part of himself by keeping away from God. She says: "I will never blame you son for your behavior. But first you pay no heed to your mind following your heart and now you pay no heed to your heart following your mind. This does not work. You have to be in between, to disregard neither of them.. and remember that no one is closer than God" (Rageh 420-21). Besides, the fact that Yusuf's lung cancer proves to be a nonmalignant tumor and that he consequently recovers is highly suggestive; it implies a prospective chance of the recovery of Abed's suffering. A further suggested therapeutic idea is presented in the last scene of the script where Egypt's flag, Wafaa's and Nour's pictures are hung on the walls in Yussef's room. This highlights the idea that one has to learn his lesson and to remember his faults by always putting them ahead. This is made clear as Yusuf himself did so when he went out of prison as he tried to hang Waffa's photo on the wall and said to his mother, "This is my life's fault mother. I have to keep it ahead to always remember it and never to do over the same mistake" (Rageh 285).

Rageh's script/heterotopia highlights spirituality as highly significant. The script constructs, yet destabilizes, different empowering plans and identity models. However, inspired by Foucault's philosophy of power, only one identity context of spiritual base is proposed as the answer for all problems. This is made clear at the end of the script when Yusuf's mother summed it up that what is needed is to follow God's cause. This implies, as argued by Foucault, an acquisition of knowledge and consequently of power that are closely related in Foucault's thinking. Foucault believes spirituality to be:

the pursuit practice, and experience through which the subject carries out the necessary transformations on himself in order to have access to the truth. We will call 'spirituality' 
the set of these pursuits, practices and experiences, which may be purifications, ascetic exercises, renunciations, conversions of looking, modifications of existence, etcetera, which are not for knowledge but for the subject, for the subject's very being, the price to be paid for access to the truth.(Foucault et al, "Hermeneutics" xxiii)

Hence, Rageh's script suggests an empowering identity model that is enlightened and empowered through spirituality; keeping up with God and with our spiritual needs should inevitably lead to the attainment of knowledge and power.

Rageh's novel proves to be a typical model of narrative therapy where, Foucault's philosophical concept of heterotopia together with the frame narrative technique figure prominently as playing a therapeutic role. The novel proceeds through two major types of paralleled heterotopias: the actual heterotopia of deviation, prison, a heterotopia of compensation, where the real events of the protagonist's life occur and the fictional frame narrative heterotopia, the script and the diary as heterotopias of illusion, wherein the discharging of distress and agony takes place. However, both types of heterotopias encompass a large number of further ones where each heterotopia functions in relation to the other.

Rageh's A Quarter Citizen draws heavily on the two therapeutic steps of the distancing of agony to a different out- ofself space and the suggesting of further alternative schemes of subjectivity or rather identity building. The script/ heterotopia, therapeutically duplicates and revises the protagonist's life story and suggests preferred stories of identity building. The suggested identity models move between the extremes of the selfinterest opportunist and the perfect Christlike figure. The script has further suggested an identity that is able to achieve a state of intertextuality between heart and mind. However, at the end, only one context based on Foucault's triangle of spirituality, knowledge and power is proposed as the answer for all problems: to follow God's cause. Thus the suggested identity is one that is empowered through spirituality and the acquisition of knowledge allowed by it. Here lies the alternative preferred story of identity and the therapeutic suggestion of the script.

Besides, Rageh's script/ heterotopia, proves to be highly therapeutic as it helps Abed to achieve his three items wish-to-do list either fictionally or actually. $\mathrm{He}$ manages to reject woman and has fictionally taken his revenge. However, Abed destabilizes one item of his wish-todo-list namely, getting a different citizenship, a fact that shows a positive change in his personality.

\section{Notes}

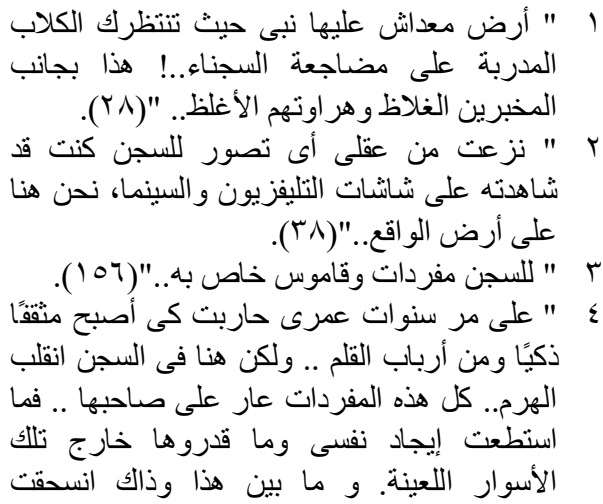

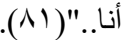




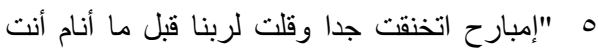

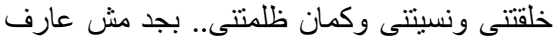
إيه اللى بيحصل دهن.. أستغفر الله العظيم.. أنا قطعت عارت

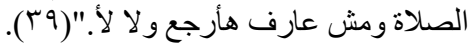
1

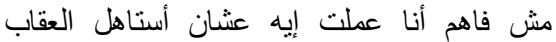

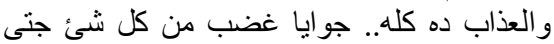
الله.. زعلان منه عشان سابنى أنظل ور ور امينى هنا.. أنا عارف كويس إن ده كفر ..." • • ـ ـ ـ ).

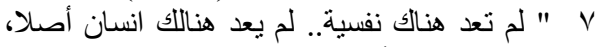
تحولت إلى آلة أهدافها الرئيسية ثنلاث:

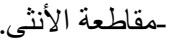

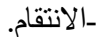

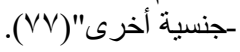

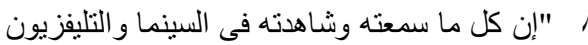

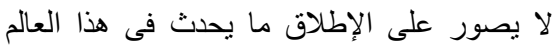

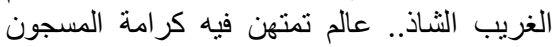

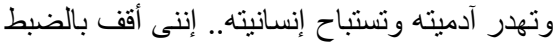

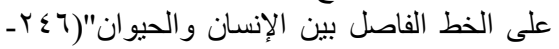
( $\varepsilon V$ 9 " أنا حاليا والحمدلله عندى ملايين ومعايا جنسية

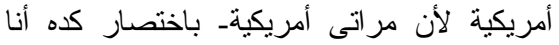

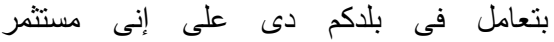

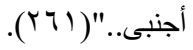

• 1 " أحلامى سأبدؤها من هنا.. غرفة وثلة مساحتها

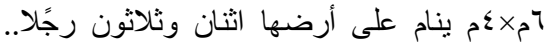

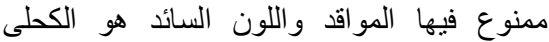

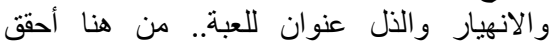

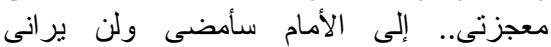
أحد"(194) 11

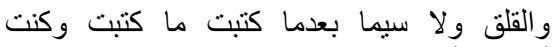

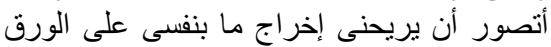

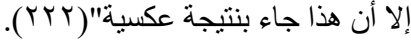

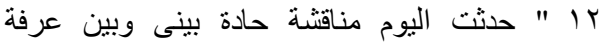
وناصر حول مصرفى عيون كل منا . .. و الغريب

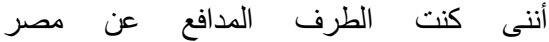
وبشر اسة" (rVo) - (rVo).

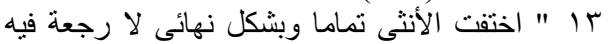

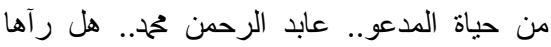

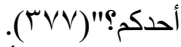

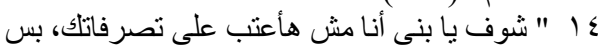

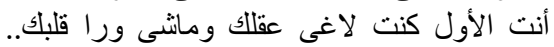

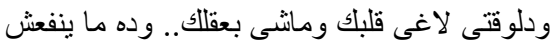

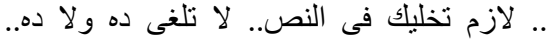

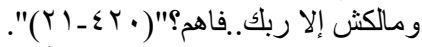
10 عشان دايما أفتكرها وا وما أغلطش تانى" (Y) (Y). 


\section{Works Cited}

Bachinger, Jacob." The Arctic and "Other Spaces" in Mary Shelley's Frankenstein". Edge.vol. 1, 2010, pp. 158-174. http://journals.library.mun.ca/ate. Accessed 3 April 2017.

Besley, Tina. "Foucauldian Influences in Narrative Therapy: an Approach for Schools". Journal of Educational Enquiry, vol.2, no. 2, 2001, pp. 72- 93. https://www.ojs.unisa.edu.au/index.php/EDEQ/article/download/559/429 . Accessed 10 Jan 2016.

Dehaene, Michiel\& Lieven De Cauter(ed). Heterotopia and The City: Public Space in a Postcivil Society. Routledge, 2008.

Dreyfus, Hubert L., et al. Michel Foucault: Beyond Structuralism·and Hermeneutics. Chicago U, 1983.

Foucault, Michel \& Miskowiec, Jay. "Of Other Spaces” Diacritics, vol. 16, no. 1, 1986, pp. 22-27. The Johns Hopkins University Press Stable. http://www.jstor.org/stable/464648. Accessed 11 April 2014

Foucault, Michel, et al. The Hermeneutics of the Subject: Lectures at the College De France, 1981-1982. Palgrave, 2005.

Irwin, Bonnie D. "What's in a Frame? The Medieval Textualization of Traditional Storytelling”. Oral Tradition. vol. 10, 1, 1995, pp.2753. www.journal.oraltradition.org/articles/download/10i? article $=i r w$ in. Accessed 11 Feb 2015.

Johnson, Peter. "Unravelling Foucault's "Different Spacess." History of the Human Sciences, vol.19, no. 4, 2006, pp. 75-90., doi:10.1177/0952695106069669. Accessed 3 Jan 2016. Accessed 20 June 2015

Knight, Kelvin. "Real Places and Impossible Spaces: Foucault's Heterotopia in the Fiction of James Joyce, Vladimir Nabokov, and W.G. Sebald". Thesis. School of Literature, Drama and Creative Writing, the University of East Anglia, 2014 .

Lotfi,Naeimeh Tabatabaei." A Unique Approach of Memory Narrative Therapy in Diasporic Contexts: An Analysis of The Bonesetter's Daughter and The Kitchen God's Wife by Amy Tan". Theory and Practice in Language Studies, vol. 4, no. 9, pp. 1912-17, September 2014. doi:10.4304/tpls.4.9.1912-1917. Accessed 5 Mars 2016.

Madigan, Stephen Patrick. "The application of Michel Foucault's philosophy in the problem externalizing discourse of Michael White". Journal of Famib 
Therapy, vol. 14, no.3,1992, pp.265-279., doi:10.1046/j..1992.00458.x. Accessed 4 July 2015.

Nicholls, Peter. "The Belated Postmodern: History, Phantoms, and Toni Morrison”. In Psychoanalytic Criticism: A Reader. Ed. SueVice. Blackwell,1996. pp.50- 74. Print.

Rageh, Mohamed. Robie Mowaaten “A Quarter Citizen”. Atlas, 2012.

Rymarczuk, Robin, \& Maarten Derksen. "Different spaces: Exploring Facebook as heterotopia." First Monday, vol.19, no.6, 2014, n. pag. Accessed. 7 Oct. 2017

Sudradjat, Iwan. "Foucault, the Other Spaces, and Human Behaviour". Procedia - Social and Behavioral Sciences.vol. 36, 2012, pp. 28 - 34. www.sciencedirect.com. Accessed 6 May 2015.

Tarr ,C. Carlyle. The Force of a Frame: Narrative Boundaries and The Gothic Novel. Thesis, The university of Georgia, 2013.

Vice, Sue. Psychoanalytic Criticism: A Reader. Cambridge: Polity, 1996. Print.

White, M. and Epston, D. Narrative Means to Therapeutic Ends. New York: Norton, 1990.

White, Michael. Narratives of therapists' lives. Adelaide: Dulwich Centre Publications, 1997.

Yahya, Haran. The Prophet Yusuf. Uthman Ibrahim Morrison, Ed. Milat Book Center., 2003. 